\title{
Strategic Planning for Human Resources, Technology, and Organizational Performance
}

Tommi Elang H, Bambang Hadi Prabowo

(STIE Jaya Negara Tamansiswa Malang)

\begin{abstract}
This study examines company profits, sales (product price multiplied by total products sold), employee performance as reflected by total production x product price, corporate social responsibility funds and employee welfare as reflected in employee income in 25 public companies listed on the IDX. Indonesian random sampling uses secondary data from annual reports published by related companies which are then quantitatively processed using the moving average autoregression method. We find that corporate social responsibility along with sales, employee performance and employee welfare is positively related to company profits.
\end{abstract}

Keywords : Corporate Social Responsibility, Indonesia, Corporate Performance

\section{Background}

Managing human resources requires careful planning starting from the recruitment process, placement and development of human resources. Human resource planning must consider the criteria for the organization's needs for human resources, starting from the level of expertise required, the type of work and various other complex criteria (Davis \& Fowler,2020).

The human resources department must know the organization's business needs for human resources and understand which departments need additional human resources, which departments need excess human resources which human resources need to be developed and so on. The human resources department must of course be managed by people who are experts in the field of human resource management (Crumpton \& Bird,2020).

Various possible risks that may occur must be a concern in human resource management, such as fraud in the selection process that causes the organization to fail to find employees who meet the needs. Other risks such as corruption and work that is not done properly, the risk of discrimination in the work environment and so on. These things must be considered and managed by means of a transparent selection process that is closely monitored, a transparent and accountable financial bureaucracy, discipline and work ethics that are upheld and so on (Golensky \& Hager,2020).

The use of high technology is able to provide assistance in human resource management such as CCTV, office computer activity monitoring software, human resource management software, 
accounting software and all of this software can be integrated into cloud computing which can be monitored in real-time and from anywhere (Davies \& Fennelly,2019).

There are at least three post investments to ensure the quality of human resources, namely technology, preparation of strategic plans, implementation and supervision of these strategic plans. These three things will have an impact on organizational performance which can be measured from the growth in the company's net profit (Itika,2011).

\section{Literature Review}

Professional human resource management must understand the organization's need for human resources and provide the human resource organization needed and maintain and improve the performance of human resources in order to make the best contribution to the organization (Widarni \& Bawono, 2020). Human resource management plays an important role in achieving organizational goals.

Human capital investment in human resources is an important thing in human resource management to improve organizational performance. Human resource management also needs to invest in itself. This is to provide the best support for human resource management needs for the organization (Armstrong \& Taylor,2020).

Human resource management can invest in human resource management technology along with adequate human resource monitoring and control tools, ranging from human resource management software to CCTV equipment and so on. Human resource management has an important impact on the sustainability of the company (Martinetti et al,2020).

Human resource management can also invest its budget for strategic human resource planning in consultation with experts from various fields related to human resource management strategic planning along with the implementation of such strategic planning. This is important because strategic planning is related to the sustainable achievement of human resource management goals to provide quality human resources for the organization (Boxall et al,2008).

\section{Research Method}

This research examines investment in human resource strategic planning, technology investment, budget absorbed by the implementation and supervision of human resource strategic planning, and organizational performance as reflected in the growth of corporate profits in 25 public companies listed on the Indonesia Stock Exchange by random sampling using secondary data from annual reports published by related companies which are then processed quantitatively using the moving average autoregression method with the following equation:

$\mathrm{Y}_{\mathrm{t}}=\mathrm{C}_{\mathrm{t}}+\beta_{1} \mathrm{SP}_{\mathrm{t} 1}+\beta_{2} \mathrm{~T}_{\mathrm{t} 2}+\beta_{3} \mathrm{~B}_{\mathrm{t} 3}+\mathrm{et}$

Where,

$\mathrm{Y}=$ Company Profit Growth

$\mathrm{C}=$ Constant 
$\mathrm{SP}=$ Strategic Human Resources Investment Planning

$\mathrm{T}=$ Technology Investment

$\mathrm{B}=$ Budget Absorbed Implementation and Supervision of Strategic Human Resources Planning

$\mathrm{e}=$ Error Term

All variables are calculated in USD.

\section{Result and Discussion}

The estimation results are as follows:

$\mathrm{Y}=10193.9892003+67.7864879962 * \mathrm{~B}+3.07724754925 * \mathrm{SP}+27.54136058 * \mathrm{~T}$

From the estimation results, the Human Resources Strategic Planning Investment (SP) is a variable that is positively related to the growth of company profits along with the Technology Investment variable (T), and the Absorbed Budget for the Implementation and Supervision of Strategic Human Resource Planning (B). Where the variable that has the most strong influence on profit growth is the Strategic Human Resources Investment Planning (SP). When the Human Resources Strategic Planning (SP) Investment increases by $3 \%$, it can increase the profit by $1 \%$. Table 1 illustrates the estimation results as follows:

Table 1. Estimation Results

\begin{tabular}{|l|r|r|r|r|}
\hline Variable & Coefficient & Std. Error & t-Statistic & Prob. \\
\hline C & 10193.99 & 3649.788 & 2.793036 & 0.013 \\
\hline B & 67.78649 & 13.6027 & 4.983313 & 0.0001 \\
\hline SP & 3.077248 & $4.55 \mathrm{E}+00$ & 0.675866 & $5.09 \mathrm{E}-01$ \\
\hline T & 27.54136 & $8.81 \mathrm{E}+00$ & 3.127857 & $6.50 \mathrm{E}-03$ \\
\hline R-squared & 0.85231 & Mean dependent var & 578336.7 \\
\hline Adjusted R-squared & 0.84312 & S.D. dependent var & 207669.3 \\
\hline S.E. of regression & 4924.982 & Akaike info criterion & 20.01889 \\
\hline Sum squared resid & $3.88 \mathrm{E}+08$ & \multicolumn{2}{|c|}{ Schwarz criterion } & 20.21803 \\
\hline Log likelihood & $-1.96 \mathrm{E}+02$ & Hannan-Quinn criter. & 20.05776 \\
\hline F-statistic & 11255.43 & \multicolumn{4}{|c|}{ Durbin-Watson stat } & 1.560344 \\
\hline Prob(F-statistic) & \multicolumn{3}{|c}{0} \\
\hline
\end{tabular}

Based on the estimation results described in Table 1., it can be seen that the R-square is very high so that changes in Human Resources Strategic Planning Investment (SP), Technology Investment (T), and Absorbed Budget Implementation and Supervision of Human Resource Strategic Planning (B) have a positive impact to the company's profit growth which is significant and can be accounted for with a level of truth of $85 \%$.

\section{Conclusion}

Human Resource Strategic Planning (SP) Investment, Technology Investment (T), and Absorbed Budget Implementation and Supervision of Human Resource Strategic Planning (B) have a strong enough influence on company profits. Where every 3\% increase in Human Resource Strategic Planning (SP) investment will be followed by a $1 \%$ increase in company profit growth. This proves that the Human Resources Strategic Planning (SP) investment is proven to be able to increase the 
company's profit growth. Where the company's profit growth is a reflection of the performance of the business organization.

\section{Reference :}

Armstrong,M., Taylor,S.(2020).Armstrong's Handbook of Human Resource Management Practice. London: Kogan Page Publishers

Boxall,P., Purcell,J. ,Wright,P.(2008).The Oxford Handbook of Human Resource Management. Oxford : Oxford University Press

Crumpton,M.A., Bird,N.J.(2020).Emerging Human Resource Trends in Academic Libraries.Lanham : Rowman \& Littlefield.

Davis,D.R., Fowler,D. J.(2020).Human Resources for School Leaders: Eleven Steps to Utilizing HR to Improve Student Learning. Lanham : Rowman \& Littlefield

Davies,S.J., Fennelly,L.J.(2019).The Professional Protection Officer: Practical Security Strategies and Emerging Trends. Cambridge: Butterworth-Heinemann.

Golensky,M., Hager,M.(2020).Strategic Leadership and Management in Nonprofit Organizations: Theory and Practice. Oxford : Oxford University

Itika,J.(2011).Fundamentals of Human Resource Management: Emerging Experiences from Africa. Ann Arbor : African Studies Centre

Martinetti,A., Demichela,M., Singh,S.(2020).Applications and Challenges of Maintenance and Safety Engineering in Industry 4.0. Hershey: IGI Global

Widarni,E.L., Bawono,S.(2020).Fundamentals of International Human Resource Management: The Basic Strategy of Optimizing Multinasional Organization Performance.Munich : BookRix GmbH \& Co.KG 